\title{
ANALISIS KAPASITAS RUANG PARKIR OFF STREET RUMAH SAKIT HERLINA KOTA SORONG
}

\author{
Fadhil Ahmad Afrisal \\ Program Studi Teknik Sipil Universitas Muhammadiyah Sorong \\ Jalan Pendidikan No 27 Kota Sorong, Propinsi Papua Barat \\ Email :fahrilahmad66@gmail.com
}

\begin{abstract}
ABSTRAK
Rumah Sakit Herlina Kota Sorong merupakan salah satu pusat kegiatan dalam bidang pelayanan jasa untuk mengurus masyarakat yang sakit yang ada di Kota Sorong yang terletak di Kelurahan Malawei di jalan Selat Makassar no. 7 Remu, dan berada berdampingan dengan Pasar Kota juga mudah dijangkau oleh angkutan umum maupun kendaraan pribadi. Faktor ini yang membuat pasien maupun yang berkunjung ke Rumah Sakit Herlina semakin lama semakin bertambah, apalagi pada saat ada kegiatan di Rumah Sakit Herlina misalnya adanya penawaran marketing obat-obatan terhadap pihak Rumah Sakit Herlina bertambah banyak sehingga menyebabkan kapasitas parkir tidak mencukupi juga kurangnya areal parkit di Rumah Sakit Herlina Kota Sorong, hal ini menyebabkan permasalahan dalam skripsi ini bagaimana kapasitas parkir di Rumah Sakit Herlina Kota Sorong apakah cukup untuk menampung jumlah kendaraan yang ada. Tujuan dari penelitian ini untuk mengetahui kapasitas statis dan kapasitas dinamis ruang parkir sepeda motor off street di Rumah Sakit Herlina Kota Sorong dengan mengidentifikasi permasalahan perparkiran sepeda motor sehingga dapat memberikan alternatif penyelesaian masalah perpakiran di Rumah Sakit Herlina Kota Sorong. Metode yang digunakan untuk menganalisis hasil penelitian ini antara lain analisis karakteristik parkir dari Hobbs 1995, pendekatan rumus Z (Pignataro), dan kebutuhan ruang parkir dari Direktorat Jendral Perhubungan Darat 1996. Data yang didapat dari hasil survai di lapangan dimasukkan ke dalam tabel kemudian dengan menggunakan program Spreadsheet data tersebut diolah dengan cara mencocokkan nomor plat dan waktu sepeda motor yang masuk dan sepeda motor yang keluar, sehingga diperoleh jumlah sepeda motor yang masuk, keluar dan parkir serta lama parkir.
\end{abstract}

Kata Kunci : kapasitas ; ruang parkir ; rumah sakit herlina 


\section{Latar Belakang}

Kota Sorong adalah kota yang saat ini berusaha berkembang seperti halnya kota-kota besar lainnya yang ada di Indonesia. Rumah sakit merupakan unit fasilitas untuk pelayanan umum dalam hal ini perawatan terhadap orang sakit. Sebagai fasilitas umum maka rumah sakit harus memberikan pelayanan kepada masyarakat tanpa harus memperhitungkan untung rugi. Disamping itu diharapkan rumah sakit sebagai unit kegiatan harus mampu memberikan kontribusi sekaligus pelayanan yang memuaskan kepada para pengguna rumah sakit. Kelurahan Malawei jalan Selat Makassar terutama Rumah Sakit Herlina Kota Sorong merupakan salah satu pusat kegiatan dalam bidang pelayanan jasa untuk mengurus masyarakat yang sakit yang ada di Kota Sorong. . Dalam pelayanannya rumah sakit juga sebaiknya memberi pelayanan yang baik dalam hal transportasi karena transportasi merupakan elemen dasar infrastruktur yang dapat mempengaruhi pola berkembangan wilayah. Perjalanan dari titik ke titik di suatu daerah berubah dari waktu ke waktu, akibat pertumbuhan penduduk, kebutuhan beragam kegiatan seperti retail, usaha, perumahan, pendidikan, hotel tak terkecuali rumah sakit. Tingkat kesehatan semakin meningkat yang tidak diiringi dengan peningkatan kapasitas pelayanan perjalanan, pada akhirnya menyebabkan tundaan lalu lintas, aksesibilitas atau tingkat pelayanan menjadi menurun dan kemudian merubah pola perkembangan wilayah. Pelayanan berupa parkir yang nyaman dan efisien merupakan salah satu pelayanan yang harus dipenuhi oleh setiap pusat kegiatan manapun termasuk rumah sakit karena sudah merupakan penunjang kelancaran kegiatan yang akan dilakukan di lokasi tersebut serta dapat membantu pola perkembangan wilayah. Setiap pengguna lahan untuk suatu pusat kegiatan, sebaiknya parkir di luar badan jalan (off-street parking). Sebab bila tidak, maka akan terjadi parkir di badan jalan (on-street parking) yang akan mengakibatkan penyempitan lebar efektif badan jalan sehingga timbul gangguan terhadap arus lalu lintas terutama saat kendaraan akan parkir maupun keluar dari tempat parkir, untuk itu perlu dilakukan penelitian terhadap kondisi ruang parkir Rumah Sakit Herlina Kota Sorong guna mengetahui kapasitas ruang parkir yang ada disana kemudian dievaluasi secara lebih lanjut sehingga menghasilkan parkir yang efektif dan efesien yang mampu menampung jumlah kendaraan yang ada, serta mengantisipasi pertumbuhan kendaraan yang semakin meningkat pesat agar tidak terjadi permasalahan kekurangan kapasitas parkir akibat penumpukan kendaraan pada masa mendatang.

\section{Tujuan Penelitian}

Tujuan dari penelitian ini untuk mengetahui kapasitas statis dan kapasitas dinamis ruang parkir sepeda motor off street di Rumah Sakit Herlina Kota Sorong dengan mengidentifikasi permasalahan perparkiran sepeda motor sehingga dapat memberikan alternatif penyelesaian masalah perpakiran di Rumah Sakit Herlina Kota Sorong.

\section{STATE OF THE ART}

Adapun penelitian terdahulu yang terkait dengan penelitian ini adalah sebagai berikut :

1. Menurut Sutapa, I. K., Suthanaya, P. A., \& Suweda, I. W. (2008) dengan judul penelitian Analisis Karakteristik dan Pemodelan Kebutuhan Parkir Pada Pusat Perbelanjaan di Kota Denpasar didapat kan hasil yaitu analisis hubungan kebutuhan parkir dengan parameter-parameter pusat perbelanjaan didapat hubungan yang memberikan tingkat akurasi terbaik serta memenuhi syarat pengujian statistik. Hubungan kebutuhan parkir mobil dengan jumlah karyawan tidak tetap (X5) yaitu persamaan regresi $\mathrm{Y} 1=-1,805+0,358 . \mathrm{X} 5$ dengan koefisien determinasi $(\mathrm{R} 2)=0,965$ dan standar kebutuhan parkirnya terhadap jumlah karyawan tidak tetap sebesar 1,097 SRP/orang. Hubungan kebutuhan parkir sepeda motor dengan karyawan tidak tetap (X5) yaitu persamaan regresi Y2 $=-24,497+2,059$.X5 dengan koefisien determinasi $(\mathrm{R} 2)=0,873$ dan standar kebutuhan parkirnya terhadap jumlah karyawan tidak tetap sebesar 6,205 SRP/orang. Hubungan kebutuhan parkir taksi dengan jumlah karyawan tidak tetap (X5) yaitu persamaan regresi Y3 $=-1,262+0,037 . X 5$ dengan koefisien determinasi $(\mathrm{R} 2)=0,873$ dan standar kebutuhan parkirnya terhadap jumlah karyawan tidak tetap sebesar 0,001 SRP/orang. Hasil analisis keterkaitan antara variabel bebas yang ditinjau terhadap kebutuhan parkir sebagian besar memiliki korelasi yang sangat kuat. Untuk kebutuhan parkir mobil variabel bebas yang signifikan hanya dipengaruhi jumlah karyawan tidak tetap (X5) dengan persamaan model Y1 = $1,805+0,358$. (X5) dengan koefisien determinasi $(\mathrm{R} 2)=0,965$. Untuk kebutuhan parkir sepeda motor variabel bebas yang signifikan dipengaruhi oleh kombinasi jumlah karyawan tetap (X4) dan jumlah karyawan tidak tetap (X5) dengan persamaan model Y2 $=135,401-1,200 .(\mathrm{X} 4)+2,829 .(\mathrm{X} 5)$ koefisien determinasi $(\mathrm{R} 2)=$ 0,972. Sedangkan kebutuhan parkir taksi

2. Menurut Suthanaya, P. A. (2010) dengan judul penelitian Analisis karakteristik dan kebutuhan ruang parkir pada pusat perbelanjaan di Kabupaten Badung didapatkan hasil Hasil yaitu kajian menunjukkan bahwa, untuk kendaraan ringan, indeks parkir dengan akumulasi parkir rata-rata sebesar 0,72. Sedangkan untuk sepeda motor, indeks parkir dengan akumulasi parkir rata-rata sebesar 3,09. Model hubungan antara akumulasi parkir 
rata-rata kendaraan ringan dengan luas bangunan untuk hari kerja adalah $2899,00160,+=x y(R 2=0,8786)$ dan sepeda motor adalah $, 6912300320,+=x y(R 2=0,5776)$. Sehingga dapat ditentukan bahwa untuk luas bangunan maksimum $75.648 \mathrm{~m} 2$ diperlukan akumulasi parkir rata-rata per jam sebesar 178 kendaraan ringan per jam dengan 194 petak dan 434 sepeda motor per jam dengan 1.209 petak. Untuk luas bangunan minimum $5.000 \mathrm{~m} 2$ diperlukan akumulasi parkir rata-rata per jam sebesar 19 kendaraan ringan per jam dengan 21 petak dan 141 sepeda motor per jam dengan 393 petak.

3. Menurut Wikrama, A. J. (2010) dengan judul penelitian Analisis Karakteristik dan Kebutuhan Parkir di Pasar Kreneng didapatkan hasil yaitu analisis diperoleh karakteristik parkir adalah sebagai berikut: untuk off street parking, volume parkir tertinggi selama 9 jam pengamatan adalah sepeda motor sebesar 2.768 kend. Rata-rata lamanya parkir tertinggi adalah kendaraan ringan sebesar $1,953 \mathrm{jam} / \mathrm{kend}$. Akumulasi tertinggi adalah sepeda motor sebesar $473 \mathrm{kend} / \mathrm{jam}$ yang terjadi antara jam 05.00-06.00. Kapasitas parkir tertinggi adalah sepeda motor sebesar $171 \mathrm{kend} / \mathrm{jam}$. Indeks parkir tertinggi adalah sepeda motor sebesar 2,8. Untuk on street parking, volume parkir tertinggi selama 9 jam pengamatan adalah sepeda motor sebesar 782 kendaraan terjadi di Jalan Rijasa. Rata-rata lamanya parkir tertinggi adalah kendaraan ringan sebesar 2,340 jam/kend terjadi di Jalan Kamboja. Akumulasi tertinggi adalah sepeda motor sebesar 220 kend/jam yang terjadi di Jalan Rijasa antara jam 05.00-06.00. Kapasitas parkir tertinggi adalah sepeda motor sebesar 57 kend/jam yang terjadi di Jalan Rijasa. Indeks parkir tertinggi adalah sepeda motor sebesar 3,860 yang terjadi di Jalan Rijasa. Jumlah petak parkir yang dibutuhkan di dalam Pasar Kreneng untuk sepeda motor dan kendaraan ringan masing-masing sebanyak 618 dan 67 petak, di Jalan Kamboja 41 petak kendaraan ringan, di Jalan Rampai 82 petak sepeda motor dan 42 petak kendaraan ringan, di Jalan Rijasa 182 petak sepeda motor dan 34 petak kendaraan ringan.

4. Menurut Anwar, R. F. (2018) dengan judul penelitian Analisis Kapasitas Ruang Parkir Sepeda Motor OffStreet Di Fakultas Tarbiyah Dan Keguruan Uin Raden Intan Lampung didapatkan hasil yaitu pelataran parkir yang ada saat ini di Rumah Sakit Telogorejo Semarang untuk sepeda motor memiliki luas area parkir efektif 467,18 m2 dengan kapasitas statis 171 SRP dan kapasitas dinamis 1.435 sepeda motor pada hari puncak. Berdasarkan hasil perhitungan dan hasil survai lapangan kebutuhan ruang parkir berdasarkan jumlah akumulasi terbesar yaitu pada hari selasa sebesar 247 SRP maka untuk saat ini tidak dapat melayani kebutuhan yang ada, hanya saja untuk kondisi Hari Minggu masih biasa melayani kebutuhan yang ada, dikarenakan berkurangnya kegiatan yang ada di Rumah Sakit Telogorejo Semarang.

\section{METODE}

\section{Tahapan Penelitian}

Tahapan penelitian yang digunakan adalah sebagai berikut :

1. Mengidentifikasi permasalahan parker di Rumah Sakit Herlina Kota Sorong.

2. Melakukan survey pendahuluan dengan wawancara.

3. Melakukan observasi lapangan dan pengumpulan data.

4. Melakukan pengolahan data yang telah didapat.

5. Melakukan analisis data dan pemecahan permasalahan.

Semua metode penulisan dan analisa dalam artikel ilmiah ini merujuk pada panduan penulisan tugas akhir Fakultas Teknik Universitas Muhammadiyah Sorong tahun 2014 (Pristianto, Amri, \& Rusdi, 2014).

\section{REFERENSI}

1. Sutapa, I. K., Suthanaya, P. A., \& Suweda, I. W. (2008). Analisis Karakteristik dan Pemodelan Kebutuhan Parkir Pada Pusat Perbelanjaan di Kota Denpasar. Jurnal Ilmiah Teknik Sipil, 12(2).

2. Suthanaya, P. A. (2010). Analisis karakteristik dan kebutuhan ruang parkir pada pusat perbelanjaan di Kabupaten Badung. Jurnal Ilmiah Teknik Sipil, 14(1).

3. Wikrama, A. J. (2010). Analisis Karakteristik dan Kebutuhan Parkir di Pasar Kreneng. Jurnal Ilmiah Teknik Sipil.

4. Pristianto, H., Amri, I., \& Rusdi, A. (2014, May 9). Pedoman Penulisan Tugas Akhir Fakultas Teknik Universitas Muhammadiyah Sorong 2014. http://doi.org/10.17605/OSF.IO/4VTJM. 
5. Anwar, R. F. (2018). ANALISIS KAPASITAS RUANG PARKIR SEPEDA MOTOR OFF-STREET DI FAKULTAS TARBIYAH DAN KEGURUAN UIN RADEN INTAN LAMPUNG (Doctoral dissertation, UIN Raden Intan Lampung). 